\title{
Region Azji i Pacyfiku w procesie transformacji
}

Recenzja książki pod tytułem Prasa chińska o przemianach społecznych i kulturowych kraju w poczq̨tkach XXI wieku pod redakcją Krzysztofa Gawlikowskiego

\section{The Asia-Pacific region in transition}

A review of the book entitled Chinese press on social and cultural changes in the country at the beginning of the 21st century by Krzysztof Gawlikowski

Słowa kluczowe: prasa chińska, chińska transformacja, socjalizm z chińską chrakterystką, międzynarodowy układ sił, relacje USA - Chiny
Keywords:

Chinese press, Chinese transformation, socialism with a Chinese character, international balance of power, US-China relations 
Chiny, głównie z powodu ich rosnącej potęgi, egzemplifikują dziejową transformację $\mathrm{w}$ kierunku świata $\mathrm{z}$ wielobiegunowym układem sił $\mathrm{w}$ miejsce układu unilateralnego. Ze zrozumiałych względów proces ten przyciąga uwagę światowego establishmentu - polityków, strategów i ekspertów, którzy podejmują próby nakreślenia scenariuszy rozwoju sytuacji międzynarodowej, w tym w zakresie tak ważnych zagadnień jak globalne bezpieczeństwo czy koniunktura światowej gospodarki. Powstają ciągle nowe publikacje $^{1}$, a jedną z nich jest opublikowana niedawno książka zespołu autorów Uniwersytetu SWPS pod redakcją naukową niedawno zmarłego prof. Krzysztofa Gawlikowskiego zatytułowana Prasa chińska o przemianach społecznych $i$ kulturowych kraju w początkach xxi wieku ${ }^{2}$. Publikacja w istocie stanowi polski wkład do toczącej się światowej debaty poświęconej akomodacji wzrostu potęgi Chin przez otoczenie międzynarodowe.

Ponad wszelką wątpliwość publikacja wychodzi naprzeciw rosnącemu zapotrzebowaniu na literaturę podejmującą problematykę Państwa Środka, czy to poświęconą jego długiej historii, czy też czasom współczesnym. Tak duże zainteresowanie Chinami jest efektem wielu czynników, w tym dokonującego się na przestrzeni ostatnich czterech dekad, historycznie bezprecedensowego rozwoju, który przekształcił ten kraj z biednego, zacofanego i słabego $\mathrm{w}$ silne, nowoczesne i bogate dzisiaj państwo. Jedynie marzyciele mogli zakładać, np. w 1978 roku, gdy Deng Xiaoping jako nowy przywódca ChRL przystępował do reform, że ten komunistyczny, zacofany rozwojowo kraj stanie się drugą co do wielkości gospodarką świata, z ogromną szansą, by wyprzedzić pod tym względem Stany Zjednoczone ${ }^{3}$. Licząca

1 Godna polecenia m.in. z uwagi na wątek relacji Chiny - USA jest niedawno opublikowana książka Roberta Zoellicka, America in the world. A history of U.S. diplomacy and foreign policy, Twelve, New York 2020.

2 Prasa chińska o przemianach społecznych $i$ kulturowych kraju w początkach XXI wieku, red. K. Gawlikowski, Wydawnictwo Akademickie Sedno, Uniwersytet SWPS 2020, ss. 528 .

3 Dane statystyczne Międzynarodowego Funduszu Walutowego za rok 2019 wykazują, że gospodarki Chin i Stanów Zjednoczonych zajmują naprzemiennie miejsca pierwsze bądź drugie, w zależności od metody liczenia PKB. I tak, przy wyliczeniu wielkości PKB na podstawie parytetu siły nabywczej (PPP) wartość PKB Chin wyniosła 27,309 bln, a PKB USA - 21,439 bln dolarów międzynarodowych. Odwrotnie wygląda ranking przy metodzie liczenia PKB na podstawie cen bieżących w dolarach USA. W tym wypadku na miejscu pierwszym są USA z PKB o wartości 21,439 bln, a na drugim Chiny z PKB o wartości 14,140 bln. Należy dodać, 
ponad pięćset stron książka jest pracą zbiorową, powstałą w Zakładzie Studiów Azjatyckich Uniwersytetu Społeczno-Humanistycznego SWPS pod redakcją naukową prof. Krzysztofa Gawlikowskiego, którego wspierały dr Małgorzata Ławacz, była konsul RP w Hong Kongu - Agnieszka Łobacz, doktorantka w Instytucie Studiów Politycznych PAN - Marta Tomczak, dr Joanna Afek oraz dr Katarzyna Golik. Tak więc nad dziełem pracował zespół wybitnych znawców języka, kultury, filozofii i problemów społeczno-gospodarczych Chin, legitymujących się studiami sinologicznymi, pracami badawczymi i publikacjami naukowymi czy nierzadko także latami spędzonymi w chińskich realiach.

\section{Prasa jako zwierciadło społeczeństwa}

Za wyjątkowy należy uznać już sam zamysł koncepcyjny książki, polegający na sięgnięciu do publikacji prasowych i niektórych periodyków chińskich, by w dość bezpośredni sposób przybliżyć polskiemu czytelnikowi Chiny i Chińczyków. Książka pozwala zorientować się, jakie problemy absorbują mieszkańców współczesnych Chin, jak funkcjonuje tamtejsza prasa w sensie wykształconego w rozwoju historycznym modelu, siły jej oddziaływania i miejsca w przestrzeni publicznej. Możliwość zapoznania się z tłumaczeniami (in extenso) wybranych tekstów prasy chińskiej w istotny sposób uzupełnia obraz przemian społecznych i kulturowych w Chińskiej Republice Ludowej, które zwykle uzyskujemy za pośrednictwem różnego rodzaju opracowań wyspecjalizowanych analityków i badaczy. Dużą pomoc w percepcji zamieszczonych w drugiej części książki tekstów z prasy chińskiej stanowią uwagi wstępne do każdego z siedmiu rozdziałów tematycznych, w których autorzy naświetlają rozliczne zagadnienia szczegółowe połączone w obszary tematyczne, takie jak: modernizacja w zderzeniu tradycją i wartościami konfucjańskimi, problemy zdrowia, edukacji i szkolnictwa wyższego, relacje władza-obywatel czy pracownik-pracodawca, problemy społeczne na tle transformacji gospodarczej, przemiany w zakresie obyczajowości i mentalności, funkcjonowanie organów porządkowych i wymiaru sprawiedliwości, zjawisko korupcji, specyficzne chińskie instytucje, stosunki międzyludzkie,

iż dość istotna różnica istnieje, jeśli chodzi o PKB per capita. Według danych IMF za rok 2019 USA z wartością 65,111 USD plasują się w światowym rankingu na 7 miejscu, a Chiny z wartością 10,980 USD na miejscu 65. 
przemiany w stratyfikacji społeczeństwa, w tym położenie klasy średniej, układ stosunków miasto-wieś, dynamika przemian relacji intymnych, stosunki międzypokoleniowe, w tym relacje rodzinne. Nierzadko spotkać można opinię, że prasa czy, szerzej, media, stanowią swego rodzaju zwierciadło społeczeństwa. W przedmowie autorzy zwracają jednakowoż uwagę, że tzw. "prawdy prasowe” i "prawdy z życia codziennego" nie są tożsame, a w odniesieniu do Chin i krajów cywilizacji konfucjańskiej, gdzie ważne jest przestrzeganie etykiety i rytualnych norm, istnieje ciągle różnica między zachowaniami publicznymi, a tym, co się myśli albo mówi w kręgu osób najbliższych, przy czym zakres tego rodzaju postaw jest jeszcze większy niż na Zachodzie.

Strukturalnie książka podzielona jest na dwie części, które wypełnia dziewięć rozdziałów, a dopełnienie całego dzieła stanowi aneks poświęcony obecnym kierunkom rozwoju ChRL, w tym objaśnieniu oficjalnej linii polityki Chin, realizowanej pod rządami aktualnego przywódcy Państwa Środka - Xi Jinpinga. Część pierwsza, która zawiera dwa rodziały, ma charakter wprowadzenia i retrospekcji w tym sensie, że Krzysztof Gawlikowski naświetla dziedzictwo i historię powstania ChRL, charakteryzuje główne etapy jej rozwoju, koncentrując się na przełomowych reformach Deng Xiaopinga, jak też podejmuje istotne zagadnienia przemian ustrojowych we współczesnych Chinach. Wprawdzie, jak podkreśla sam autor, jego „studium nie jest zarysem historii Chin ani nawet jej skrótowym przypomnieniem, lecz jedynie przytoczeniem podstawowych faktów i wydarzeń, które formowały współczesne Chiny i ich narodowe imagoinarium, niemniej jednak mamy $w$ tym wypadku do czynienia z godnym polecenia kompendium wiedzy, przydatnej dla wszystkich, którzy chcieliby pojmować Chiny i ich cywilizację. Z kolei A. Łobacz w tej samej pierwszej części, podejmuje problemy związane $\mathrm{z}$ tytułowym zagadnieniem chińskiej prasy, która jak sama podkreśla, w pierwszych 30 latach istnienia chRL była przede wszystkim instrumentem politycznym, służąc władzy do przekazywania dyrektyw, natomiast nie odgrywała istotnej roli jako źródło informacji o społeczeństwie ani o życiu kraju oraz - co ciekawe i wyjątkowe - nie stanowiła platformy prezentacji poglądów czy postaw opinii publicznej.

Również prasa regionalna wydawana $w$ chińskich prowincjach służyła przenoszeniu do społeczności lokalnych wytycznych władzy centralnej. Jednakże, jak podkreśla Agnieszka Łobacz, prasa terenowa była redagowana w sposób mniej propagandowo zakamuflowany z uwagi na konieczność 
bardziej konkretnego, związanego z miejscowymi problemami, przedstawiania zadań i oczekiwanych rezultatów. Zwłaszcza poprzez zalecenia korekty zamierzeń i naprawy występujących niedociągnięć pokazywała (często mimo woli) lokalną rzeczywistość w sposób bardziej otwarty. Inny ciekawy aspekt, tym bardziej że przypominający rozwiązania funkcjonujące także w polskiej socjalistycznej rzeczywistości, to rozprowadzane w zamkniętym obiegu biuletyny zawierające wiadomości i komentarze prasy zagranicznej. W warunkach chińskich były to "Cankao Xiaoxi” (Wiadomości Dokumentalne), zamieszczające przedruki serwisów agencji światowych oraz fragmenty artykułów z prasy zaǵranicznej, opatrywane własnymi tytułami redakcji, zawierającymi chińską ocenę wydarzeń, do których informacje się odnosiły. Dla kadry chińskiej były to wskazówki oficjalnej interpretacji. Ta retoryka występowała również w oficjalnych dokumentach, szczególnie w okresie Rewolucji Kulturalnej i do śmierci Mao. Emocjonalnie negatywnie nacechowane były szczególnie tytuły depesz agencyjnych dotyczących krajów i osobistości zagranicznych, które Chiny krytykowały (na przykład zamiast neutralnie brzmiącego słowa "ogłosił” czy „stwierdził” umieszczano w tytule: „krzyczal”, „kłamal”, „oczerniał” itp.) ${ }^{4}$.

Przekształcenia w sektorze prasy, a nawet szerzej - w sferze nadbudowy, pojawiają się z pewnym przesunięciem w czasie jako następstwo polityki reform gospodarczych i otwarcia zapoczątkowanego w 1978 r. przez Deng Xiaopinga. Zgodnie $\mathrm{z}$ prawami ekonomii zadziałał w owym czasie mechanizm rynku, z jednej strony wymuszając komercjalizację mediów, $\mathrm{w}$ wydawnictwach prasowych widoczną bardziej niż $\mathrm{w}$ radiu czy $\mathrm{w}$ telewizji, a z drugiej zmieniając rzesze czytelników, dyskontujących rozwój gospodarczy w postaci sukcesywnie poprawiających się standardów życia. Warto podkreślić za Autorką, że odnosiło się to przede wszystkim do gospodarki, natomiast w sferze nadbudowy czynnik rynku, a także „otwarcie”, które umożliwiało szersze kontakty ze światem zewnętrznym i oznaczało odwilż w życiu politycznym i społecznym wewnątrz państwa, znalazły odzwierciedlenie dopiero później. Metamorfozie uległy również dzienniki prowincjonalne - poza organami prowincjonalnych komitetów partii - w znacznej mierze sprywatyzowane, choć nadal wydawane pod auspicjami lokalnych

4 Gwoli ścisłości należy wyjaśnić, że wydawany w PRL Biuletyn Informacyjny PAP zawierał także przedruki z prasy zagranicznej, ale wolny był od tak wyrafinowanej jak w Chinach manipulacji propagandowej. 
władz z obowiązkowym działem informacji ogólnokrajowych, czyli skoncentrowanych na aktywności władz centralnych, a przede wszystkim głowy państwa. Zasięg ogólnochiński miał powstały wówczas periodyk "Qiushi" (Poszukiwania Prawdy) - organ Komitetu Centralnego Komunistycznej Partii Chin, wydawany od lipca 1988 roku do dzisiaj. Jako czasopismo ideologiczno-teoretyczne i platforma badawcza periodyk dostarcza interpretacji teorii stanowiących podstawę formułowanych celów w polityce, gospodarce i kulturze i daje możliwość odczytania uwarunkowań, które podyktowały dane cele. Pozwala również umiejscowić wprowadzane odgórnie skrótowe specyficzne hasła w chińskim kontekście społecznym i odnieść je do chińskich kodów kulturowych. Jako intelektualnie bardziej wymagające, odpowiadające na potrzeby nowej, dobrze wykształconej generacji działaczy partyjnych i państwowych pismo to jest kontynuacją oficjalnego miesięcznika naczelnych władz partii - „Hongqi” (Czerwony Sztandar), ukazującego się w latach 1958-1988, który zamieszczał oficjalne dokumenty i przeznaczone do upublicznienia przemówienia oraz wstępne artykuły redakcyjne. Od lipca 2009 roku ma wydanie internetowe, a od października 2019 roku, i na to należy zwrócić szczególną uwagę badaczy, ukazuje się edycja anglojęzyczna - "Qiushi Journal”. Naukowy charakter ma wydawany od 1993 roku przez Chińskie Stowarzyszenie Badań Strategicznych, ceniony przez analityków i akademików dwumiesięcznik „Zhanlue yu guanli” (z podtytułem "Strategy and Management”). Poczesne miejsce zajmuje tygodnik "Liaowang” (Obserwacje) wydawany przez oficjalną agencję Xinhua po chińsku (z podtytułem „Outlook”), który zajmuje się przede wszystkim szeroko rozumianą tematyką społeczną, zbierając materiały w terenie, u źródeł. Tygodnik publikuje również liczne materiały dotyczące gospodarki i komentarze na tematy międzynarodowe, których autorami są głównie politolodzy z najbardziej znanych chińskich think tanków. Ciekawą obserwację w odniesieniu do treści publikowanych we wspomnianym tygodniku "Liaowang” poczynił kiedyś Zbigniew Brzeziński, który podkreślał, że niektóre jego publikacje poświęcone problematyce międzynarodowej sygnalizowały pewne wątpliwości co do ogólnego historycznego uzasadnienia obecnego globalnego status quo, a także wysuwały do pewnego stopnia doktrynalne roszczenia, przydając obecnemu modelowi chińskiemu cechy uniwersalne ${ }^{5}$.

5 Zob.: Z. Brzezinski, Strategic vision: America and the crisis of global power, Basic Books, New York 2012, s. 83. 
Godny uwagi w opinii Agnieszki Łobacz jest dwutygodnik „Ershiyi Shiji Shangye Pinglun" (21st Century Business Review) z podtytułem po chińsku „Puls Nowego Biznesu”. Adresowany jest do prężnych przedsiębiorców, a także przyznaje naǵrody - Model biznesu XXI wieku i Najlepszy Przedsiębiorca Chiński - wzorzec XXI wieku. Czasopismo poświęca wiele uwagi firmom chińskim, czerpiącym wzory z zagranicy, przede wszystkim z korporacji amerykańskich, lecz nie pomija nowo pojawiających się wyzwań społecznych. W podsumowaniu Autorka podkreśla, że omówione w książce przykłady wydawnictw prasowych z pierwszych kilkunastu lat XXI wieku wydają się najbardziej interesujące i reprezentatywne dla zilustrowania, jak różnorodna jest współczesna prasa chińska, i jak rozmaite treści zawiera. Przy oczywistych uproszczeniach i fragmentaryczności tego opisu oraz zamieszczonych w tomie materiałów - reportaż z jednej miejscowości nie może być traktowany jako obraz całego, tak ogromnego, kraju dają one pewien wgląd w życie Chin na początku XXI wieku oraz wyobrażenie o skali problemów i złożoności wyzwań, przed którymi stoją Chiny nowej ery, ery „chińskiego marzenia”.

\section{Państwo komunistyczne epoki Mao}

W obszernym wprowadzeniu, zatytułowanym Uwarunkowania procesów transformacji $w$ Chinach $i$ roli prasy Krzysztof Gawlikowski wykazuje, iż w Chinach komunizm utożsamiano z prastarym ideałem Konfucjańskiego Wielkiego Zjednoczenia, uznawanego za najdoskonalszy system społeczny, będący utopijnym marzeniem filozofów i polityków przez ponad dwa tysiące lat. Państwo komunistyczne epoki Mao realizowało konfucjański ideał państwa wszechobecnego i niemal omnipotentnego, w pełni odpowiadającego za dobrobyt ludu, organizującego życie społeczne, gospodarcze i moralne formowanie społeczeństwa, a on sam był przedstawiany jako władca-mędrzec zaprowadzający w kraju ład moralny i społeczny na podobieństwo idealnych władców konfucjańskich. Dlatego dla wielu Chińczyków do dziś Mao jest nie tylko otoczonym czcią twórcą niepodległych Chin, ale i wielkim moralistą społecznym. Podkreślić wypada istotną konstatację Autora, iż tęsknoty do jego (Mao) epoki i próby ich politycznego wykorzystywania są częścią krajobrazu politycznego współczesnych Chin, a w dość szerokich kręgach ludowych - wbrew oficjalnej propagandzie partyjnej jest on nawet postacią otoczoną kultem religijnym. 
Przypomnieć należy, że rodowód ChRL, podobnie jak Rosji Sowieckiej, pozostaje $\mathrm{w}$ ścisłym związku $\mathrm{z}$ ideami ruchu komunistycznego, teorią i praktyką rewolucji proletariackiej, których teoretyczne podstawy stworzył Karol Marks i co znalazło rozwinięcie w ideologii marksizmu-leninizmu. Ten aspekt akcentuje prof. Jan Rowiński, pisząc, iż w tzw. rewolucyjnym okresie historii ChRL, obejmującym lata 1949-1977, prowadzona była polityka będąca $\mathrm{w}$ istocie powielaniem radzieckiego modelu rozwoju $\mathrm{z}$ pewną domieszką woluntarystycznych koncepcji Mao Zedonga ${ }^{6}$. W ten sposób maoistowski etap rozwoju ChRL charakteryzował się gównie kopiowaniem sowieckiego modelu rozwoju w sferze ideologicznej, politycznej, gospodarczej, społecznej i militarnej, a całość dopełniły katastrofalna w skutkach koncepcja Wielkiego Skoku i tworzenie komun ludowych na wsi (19581960) oraz okupiona wielką liczbą ofiar i destrukcyjna z punktu widzenia potrzeb społeczno-gospodarczego rozwoju „wielka proletariacka rewolucja kulturalna” w latach 1966-1976. Ta ostania przebiegała pod hasłami "permanentnej rewolucji” ze "stale zaostrzającą się walką klasową" $i$ "pościgiem za światem" w warunkach niekończących się ogólnokrajowych kampanii kształcenia ideologicznego.

$\mathrm{Na}$ istotny aspekt dotyczący rozwoju systemu politycznego Chin po 1949 r. zwraca uwagę Francis Fukuyama, który podkreśla ${ }^{7}$, iż państwo chińskie w okresie maoistowskim zostało całkowicie upolitycznione poprzez podporządkowanie Chińskiej Partii Komunistycznej, niemniej rozpadło się prawie całkowicie podczas rewolucji kulturalnej, podobnie jak struktury samej partii. W jego opinii państwo zostało zdominowane nie przez polityków w rozumieniu zachodnim, ale przez zdyscyplinowaną partię leninowską, zbudowaną wokół elitarnego rdzenia, z zastępami członków wykorzystywanych do penetracji reszty społeczeństwa. Przed rewolucją kulturalną członkowie KPCh stanowili 2,5 procent całej populacji Chin. Dziś partia liczy około 90,6 mln członków, czyli ponad 6 procent ogółu mieszkańców. Hierarchiczne struktury partii są repliką struktur samego państwa, od lokalnych komitetów partyjnych po organy szczebla miejskiego i wojewódzkiego,

6 Zob.: J. Rowiński, Chiny. Nowa globalna potęa, [w:] Dokąd zmierza świat, red. A. D. Rotfeld, PISM, Warszawa 2008, s. 350-351.

7 F. Fukuyama, Political order and political decay. From the Industrial Revolution to the globalization of democracy, Farrar, Straus and Giroux, New York 2014, s. $272-273$. 
poprzez Komitet Centralny na poziomie krajowym, Biuro Polityczne, Stały Komitet Biura Politycznego, a na szczycie przewodniczącego partii. Kontrola nad państwem sprawowana jest przy pomocy różnych mechanizmów, a najbardziej rozpowszechniony polega na tym, iż aparat państwowy na najwyższym poziomie, tj. kierowników ministerstw i instytucji centralnych, obsadzany jest przez członka partii, który pełni w ten sposób dwie funkcje. Natomiast na poziomie lokalnym, w każdej dzielnicy miejskiej i wiosce, grupa robocza jest nadzorowana przez kadrę partyjną.

Z kolei samego Mao Zedonga charakteryzuje m.in. Odd A. Westad, prof. historii i spraw globalnych amerykańskiego Uniwersytetu Yale, który w książce Restless Empire podkreśla, że linia polityczna Mao Zedonga ukierunkowana była na wytworzenie w Chińczykach przekonania, że wyłącznie ich kraj „podąża prawdziwą drogą rewolucji i rozwoju człowieka” oraz „posiada klucz do przyszłości”. Tym kluczem miał być sam Mao Zedong i jego wizja rozwoju Chin. Osobistą obsesją Mao po niepowodzeniu Wielkiego Skoku było stworzenie nowego pokolenia Chińczyków, którzy nie byliby powstrzymywani przez konformizm, w tym etykę, rodzinę czy przyjaźń przed całkowitym poświęceniem się rewolucji, nawet po jego odejściu. Marzeniem Mao były „Chiny całkowicie wolne od przeszłości, z obywatelami będącymi pustą tablicą, na której można będzie wpisywać wyższą formę nowoczesności. Widział drogę ku świetlanej przyszłości, wyłożoną zwłokami tych, którzy popełnili błąd lub po prostu mu przeszkodzili" ${ }^{8}$. Ostatnią drabiną do raju w pojęciu Mao - pisze Westad - miała być jego rewolucja kulturalna, ze stosami ciał, tak jak zrobili przed nim Stalin i Hitler, a po nim Pol Pot.

Nowy, trwający de facto do dzisiaj etap rozwoju Chin, zapoczątkowany został pod koniec roku 1978 zasadniczymi „reformami i otwarciem na świat” przy generalnym przewartościowaniu polityki realizowanej pod rządami Mao. W opinii wielu historyków i politologów Deng Xiaoping wdrożył największe, najbardziej fundamentalne reformy, jakich Chiny doświadczyły w ciągu czterech tysięcy lat swej historii, zapisane wielkimi zgłoskami także w historii świata XX w. Krzysztof Gawlikowski podkreśla, iż w rezultacie wspomnianych reform "Chiny, będące na początku ubiegłego wieku „państwem upadłym”, deptanym przez armie mocarstw zachodnich wedle

8 O. A. Westad, Restless empire. China and the world since 1750, Basic Books, London 2012, s. 333-34. 
ich woli, gdzie nędza była niewyobrażalna, a ludzie stale umierali z głodu tysiącami, podczas klęsk żywiołowych zaś setkami tysięcy, u końca XX w. stały się "największą fabryką świata”, jego największym bankierem, a także głównym partnerem Stanów Zjednoczonych, a ponieważ proces wzrostu nadal trwa i Chiny ciągle rosną w siłę, najprawdopodobniej jeszcze w XXI w. staną się supermocarstwem ${ }^{9}$. Zgadzając się z tezami wielu innych ekspertów, jeśli chodzi o przełomowy charakter reform i polityczną determinację Denga, Gawlikowski zwraca uwagę także na inny, niezwykle istotny, związany z jego reformami aspekt, a mianowicie ich ewolucyjny charakter. Jego zdaniem zasadna jest teza, że jako całość zmiany zachodziły stopniowo, inspirowane w części oddolnie, w części odgórnie przez władze centralne albo lokalne czy regionalne na różnych szczeblach, co aktywizowało społeczeństwo. Również Henry Kissinger w wydanej w 2011 r. książce On China podejmuje i szczegółowo naświetla kwestię wyjścia Chin z fazy rujnującej kraj rewolucji kulturalnej, uwypuklając prekursorską rolę Zhou Enlaia, który od momentu powstania ChRL aż do śmierci w 1976 r. pełnił funkcję premiera ChRL. Kissinger, który w ramach przygotowań historycznej, jak się okazało, wizyty prezydenta Richarda Nixona w Chinach w 1972 r., a także potem odbył wiele rozmów, zarówno z Zhou, jak i Mao Zedongiem, szczegółowo ilustruje ten skomplikowany i pełen politycznych sprzeczności proces ${ }^{10}$. Przypomina, że śmiertelnie chory Zhou Enlai pokazał się ostatni raz publicznie w styczniu 1975 r., a okazją po temu było spotkanie Narodowego Kongresu Ludowego, pierwsze, jakie zwołano od maja 1966 r., tj. od początku rewolucji kulturalnej ${ }^{11}$. Zhou rozpoczął swoje wystąpienie zgodnie $\mathrm{z}$ obowiązującą $\mathrm{w}$ owym czasie niepisaną regułą, $\mathrm{tj}$. od wygłoszenia starannie sformułowanych pochwał rewolucji kulturalnej i kampanii antykonfucjańskiej, okrzykując ich wpływ „wielkim”, „ważnym” i „dalekosiężnym". W ocenie Kissingera była to ostatnia publiczna deklaracja lojalności wobec przewodniczącego Mao, któremu służył przez czterdzieści lat. Najważniejszy, jednakże i zaskakujący był fakt, iż w dalszej części przemówienia Zhou Enlai zaproponował zupełnie nowy kierunek polityki,

9 K. Gawlikowski, Charakter i dynamika „reform Deng Xiaopinga”, swPS, 4 VI 2014 [dostęp: 23 III 2021], dostępny w internecie: 〈https://www.swps.pl/nauka-i-badania/ materialy-ccaw/2445-charakter-i-dynamika-reform-deng-xiaopinga $\rangle$.

10 H. Kissinger, On China, The Penguin Press, NY 2011, s. 302-303.

11 H. Kissinger, On China, s. 302. 
tj. szeroko zakrojonych reform, w rzeczywistości oznaczający odrzucenie tego, co powiedział w pierwszej części swojego wystąpienia, a więc celów rewolucji kulturalnej. Faktycznie był to powrót do, po raz pierwszy zarysowanej przez niego w 1965 r., koncepcji „kompleksowej modernizacji”, obejmującej cztery kluczowe sektory: rolnictwo, przemysł, armię oraz naukę i technologię. Co ciekawe, podkreślił, że ogłasza to wezwanie "na polecenie przewodniczącego Mao", choć - jak podkreśla Kissinger - nie wiadomo, kiedy i jak zostało takowe wydane ${ }^{12}$. Zhou wezwał Chiny do osiągnięcia wspomnianej modernizacji „przed końcem wieku”. Ponadto istotna z dzisiejszej perspektywy była wyartykułowana wówczas częściowo prognoza, a częściowo rzucone wyzwanie: „do końca XX wieku chińska gospodarka narodowa rozwinie się do poziomu światowej czołówki".

Niedługo potem rewolucja kulturalna uznana została za największy błąd przewodniczącego Mao, który - co podkreśla wielu analityków - ogłosił ją w głównej mierze z pobudek osobistych, gdyż po odsunięciu od steru władzy z powodu porażki jego polityki Wielkiego Skoku Mao Zedong przystąpił do kontrofensywy, podejmując próbę rozprawienia się z przeciwnikami politycznymi przy wykorzystaniu ciągle lojalnej mu chińskiej armii. W tym celu na posiedzeniu Biura Politycznego KC KPCh 16 maja 1966 utworzona została Grupa do spraw Rewolucji Kulturalnej, w skład której weszli najbardziej radykalni działacze partyjni. Ich zadaniem miało być zwalczanie zakamuflowanych antysocjalistycznych działaczy, rzekomo ukrytych w strukturach partii, a ponadto zwalczanie starych idei, kultury i obyczajów. Doprowadziło to do prześladowań intelektualistów, niszczenia sprzętu „burżuazyjnego", zasobów muzealnych i zabytków. Zamrożone zostały stosunki z zagranicą, a Mao konsolidował swoje wpływy za pośrednictwem, inspirowanego przez niego samego, kultu jego własnej osoby, maskowanego pod szyldem niezbędnego autorytetu przewodniczącego. Rewolucja przyniosła komunistycznym Chinom destrukcję gospodarki, kultury i społeczeństwa ${ }^{13}$.

13 Katastrofalne skutki społeczno-gospodarcze przyniosły Chinom wcielane w życie już w latach 1958-1960 woluntarystyczne pomysły Mao, zwłaszcza polityka Wielkiego Skoku. Zob.: J. Rowiński, Upadek Nikity S. Chruszczowa. Czy rzeczywiście była to niewykorzystana szansa zakończenia "zimnej wojny" między Pekinem a Moskwą? Spojrzenie z Zhongnanhai, [w:] , Region Azji i Pacyfiku w latach 1985-2015, red. A. Jarczewska, J.Zajączkowski, Wydawnictwo Naukowe Scholar, Warszawa 2016, s. 169-194. 
Ogrom nieszczęścia i nierzadko desperacji odzwierciedla sytuacja z października 1978 r., a więc mająca miejsce już w dwa lata po śmierci Mao, gdy w wiosce Xiaogang we wschodniej prowincji Anhui 18 rolników potajemnie dokonało zmiany zasad uprawy ziemi. Wprowadzili oni podział gruntów rolnych, będących własnością społeczną i użytkowanych kolektywnie na oddzielne pojedyncze części, które przypisane zostały do indywidualnych domostw w oparciu o tzw. kontrakty gospodarstw domowych. Przed 1978 r. Xiaogang było nieznaną, niezwykle biedną wioską, która zyskała rozgłos w związku z buntem mieszkańców i ich ryzykowną inicjatywą mającą na celu poprawę losu. Wcześniejsze zasady organizacji uprawy ziemi polegały na tym, iż wieśniacy pracowali na polach będących własnością kolektywu w zamian za "punkty pracy”, które można było wymieniać na żywność, co jednak nie było wystarczające, by mogli utrzymać siebie i swoje rodziny. Miliony zmarły z głodu podczas Wielkiego Skoku w latach 1958-1960. Inicjatywa mieszkańców Xiaogangu, chociaż początkowo krytykowana, ostatecznie zyskała nie tylko poparcie w szerokim odbiorze społecznym, ale także akceptację kierownictwa politycznego najpierw prowincji, a potem szczebla centralnego. Jako taka była impulsem tzw. rewolucji wiejskiej w Chinach, która przyniosła z jednej strony możliwość eliminacji komun ludowych, w tym kolektywnych gospodarstw i przydziału ziemi indywidualnym rolnikom w oparciu o kontrakty, z drugiej zaś, uruchomiła brzemienną w skutki falę migracji, zbędnej siły roboczej, ze wsi do miast.

\section{Wizja Zhou Enlaia w realizacji Deng Xiaopinga}

Datą symbolizującą historyczny zwrot działań na szczeblu centralnym w postaci refom Denga, polegających na zerwaniu z polityką uosabianą przez Mao, jest 18 grudnia 1978 r., kiedy rozpoczęło obrady III Plenum Komitetu Centralnego Komunistycznej Partii Chin ${ }^{14}$. Był to faktyczny początek ery

14 Zob.: Wyzwólmy nasze umysły, poszukujmy prawdy weryfikując fakty, zjednoczmy się dla śmiałego patrzenia $w$ przyszłość. Przemówienie podsumowujące na Centralnej Konferencji Roboczej poprzedzającej III Plenum KPCh 11 Kadencji, będące zarazem głównym materiałem omawianym na tym Plenum 13 grudnia 1978 r. Programowe dokumenty chińskie z okresu reform. Wybór, opracowanie i przekład K. Gawlikowskiego, dostępny w internecie [dostęp: 23 III 2021]: <https://www. swps.pl/images/stories/dokumenty/ccaw/gawlikowski/41\%20Publikacje $\% 20-\% 20$ dokum\%20-Deng-KG-przeklady.pdf $>$. 
reform, choć Deng Xiaoping, gdy przejmował stery władzy w Pekinie, miał do pewnego stopnia otwartą drogę do realizacji zamysłu „kompleksowej modernizacji" w czterech kluczowych sektorach wykoncypowanej - jak wspomniałem wyżej - jeszcze przed rewolucją kulturalną przez Zhou Enlaia. W ten sposób zapoczątkowana po śmierci Mao i konsekwentnie wdrażana polityka reform i otwarcia na świat $w$ ciągu niespełna trzech kolejnych dekad doprowadziła Chiny w 2014 r. do drugiego po Stanach Zjednoczonych miejsca, jeśli chodzi o wielkość PKB oraz pozwoliła na rozbudowę potencjału militarnego do poziomu stawiającego Chiny pośród potęg militarnych świata. Należy podkreślić w tym miejscu, iż wg niektórych analityków Chiny w istocie zachowują nadal zdefiniowane przez Denga w 1979 r. „cztery podstawowe zasady" polityki ${ }^{15}$ : podążanie drogą socjalizmu, uznawanie dyktatury proletariatu i kierowniczej roli KPCh, marksizmu-leninizmu i myśli Mao Zedonga ${ }^{16}$. Deng domagał się ich przestrzegania nie tylko od członków KPCh, ale także od wszystkich Chińczyków, stąd wpisano je do statutu KPCh i konstytucji. Siłę oddziaływania tych zasad tonuje Krzysztof Gawlikowski, który podkreśla, iż w społecznej rzeczywistości kształtowanej pod rządami Denga wspomniane zasady miały formalny charakter, a "znacznie żywotniejsze i cieszące się popularnością były odwoływania do demokracji (czasem z dodaniem przymiotnika "socjalistycznej”), podobnie jak to, że o „dyktaturze proletariatu" wspominano już bardzo rzadko, a odwołania do marksizmu-leninizmu i myśli Mao zniknęły praktycznie z realnego dyskursu politycznego. Na specyficzną chińską rzeczywistość owego czasu, tj. po rozpoczęciu reform 1978 r., zwraca uwagę również Francis Fukuyama, który uważa, że państwo, które wówczas było tworzone, nawiązywało w większym stopniu do klasycznych wartości cesarstwa chińskiego niż do treści praktykowanych w modelu maoistycznym czy sowieckim, które Chińczycy próbowali kopiować. Faktycznie Chiny zaangażowały się w odbudowę wartości zakorzenionych w swojej dawnej historii i tradycji, niezależnie od tego, na ile świadomi bądź nieświadomi byli uczestnicy tego procesu ${ }^{17}$. Jednocześnie

15 O. Fallaci, Deng: Cleaning up Mao's mistakes, dostępny w internecie [dostęp: 23 III 2021]: 〈http://digitalcollections.library.cmu.edu/awweb/awarchive?type=fileBitem $=472059>$; Programowe dokumenty chinskie...

16 Deng Xiaoping, Chińska droga do socjalizmu. Wybór prac z lat 1956-1987, przeł. Z. Góralczyk et al., Książka i Wiedza, Warszawa 1988, s. 106.

17 F. Fukuyama, Political order..., s. 371. 
jednak tenże Fukuyama przyznaje, iż powyższa argumentacja jest do pewnego stopnia absurdalna, chociażby w zestawieniu z faktem, iż „współcześni chińscy urzędnicy służby cywilnej ani nie analizują rytuałów dworskich, ani nie studiują klasyki konfucjańskiej, ale kombinację, którą tworzą łącznie dzieła marksizmu-leninizmu, książki na temat inżynierii oraz zachodnia literatura poświęcona managementowi".

A jak przedstawiała się w tym czasie kwestia stosunku do samego Mao Zedonga? Deng przedstawił nowe spojrzenie na dokonania przewodniczącego, m.in. w wywiadzie dla włoskiej dziennikarki Oriany Falacci (sierpień 1980 r.), stwierdzając m.in., iż Mao miał 70 proc. zasług, a tylko 30 proc. błędów z naciskiem na priorytetowe znaczenie sukcesów, a drugorzędne niepowodzeń czy jego błędów. Wynikało to zapewne z poczucia przynależności do tej samej grupy rewolucjonistów i w tym sensie do współodpowiedzialności, dyktując potrzebę ochrony Mao przed nazbyt radykalnymi krytykami ${ }^{18}$.

Podobny aspekt ilustruje prof. Bogdan Góralczyk w książce poświęconej chińskiej transformacji, a zatytułowanej Wielki Renesans, zwracając m.in. uwagę na rzecz szczególną, jeśli chodzi o Deng Xiaopinga, który mimo krzywd, jakich doznał w trakcie rewolucji kulturalnej, a potem dysponując kapitałem uznania społeczeństwa, ponieważ dzielił jego ciężki los, „gdy przyszła chwila prawdy, na szali ważonych racji opowiedział się za partią i systemem, i zdecydowanie przeciwko tzw. „piątej modernizacji - demokratyzacji" ${ }^{\prime 19}$. W jego (Denga) rozumieniu demokracja nie może stanowić celu „bardziej ważnego niż społeczny spokój i stabilność”, które są nieodzowne w takim samym stopniu jak warunkująca postęp modernizacja. Jednocześnie w zasadniczy sposób Deng przeciwny był maoistycznemu egalitaryzmowi, a mając na uwadze potrzeby w zakresie rozwoju gospodarczego, przekonany był o nieodzowności otwarcia Chin na gospodarkę światową. Pod koniec grudnia $1978 \mathrm{r}$. nowe podejście znalazło odzwierciedlenie już w konkretnych, niekiedy spektakularnych posunięciach. Chiny zamówiły np. trzy samoloty typu Jumbo Jet Boeing 747 w Seattle, a koncern Coca-Cola, także w grudniu, ogłosił otwarcie produkcji w Szanghaju.

18 K. Gawlikowski, Charakter i dynamika „reform Deng Xiaopinga, SWPS, [online], 4 VI 2014 [dostęp: 23 III 2021], dostępny w internecie: 〈https://www.swps.pl/nauka-i-badania/ materialy-ccaw/2445-charakter-i-dynamika-reform-deng-xiaopinga $>$.

19 B. Góralczyk, Wielki Renesans. Chińska transformacja i jej konsekwencje, Dialog, Warszawa 2018, s. 63. 
Ponadto w 1978 r. Deng Xiaoping podjął strategiczną decyzję, aby co roku wysyłać z Chin do USA 3000 studentów i naukowców w celu dalszego kształcenia ${ }^{20}$. Na początku 1979 r. rząd Chin dokonał zmiany strategii gospodarczej, kładąc nacisk na produkcję towarów konsumpcyjnych przeznaczonych na rynki zagraniczne, zasadnie widząc w tym sposób na dopływ środków dewizowych. Była to kluczowa decyzja, otwierająca także drogę do korzystnych zmian wewnętrznych, w tym poprawy standardów życia w Chinach, jak i ich miejsca na gospodarczej mapie świata.

\section{Wokół programu „wielkiego odrodzenia narodu chińskiego”}

W Aneksie zamieszczono m.in. artykuł Shen Chunyao, wpisujący się $\mathrm{w}$ ramy toczącej się $\mathrm{w}$ Chinach od wielu lat debaty na temat kierunków reform polityczno-ustrojowych. Autor, zajmujący wysokie stanowisko $\mathrm{w}$ chińskiej hierarchii władzy ${ }^{21}$, specjalizuje się $\mathrm{w}$ kwestiach prawnych i reprezentuje nurt opowiadający się za wprowadzaniem pewnych form demokratyzacji, podczas gdy populiści, także obecni w debacie, propagują powrót do dziedzictwa Mao, a konserwatyści - umacnianie rządów autorytarnych. Przytoczony artykuł objaśnia program reform politycznych uzgodnionych na przedostatnim, XVIII zjeździe KPch w $2012 \mathrm{r}$. z koncepcją postulowanego ustroju dla ChRL - demokracji konsultatywnej, przyjętej do programu reform na XVIII zjeździe KPCh w 2012 r. Krzysztof Gawlikowski podkreśla we Wprowadzeniu, że opiera się ona na tradycyjnych dla Chin formach życia politycznego i mechanizmach podejmowania decyzji zgodnych z wartościami konfucjańskimi. Przez ponad dwa tysiąclecia - pisze K. Gawlikowski - od zwykłej rodziny aż po dwór cesarski dominowało tam bowiem nie indywidualne i arbitralne podejmowanie decyzji przez formalnego zwierzchnika, lecz w drodze wypracowywania szerszego

20 Według Johna C. Thomsona, który pracował $\mathrm{w}$ ambasadzie amerykańskiej w Pekinie, pierwsza grupa 52 chińskich intelektualistów udała się do USA 26 grudnia 1978 r. na dwuletnie studia. Szerzej na ten temat vide: Educational exchange has long enriched US-China relations, „China Daily” [online], 22 XI 2019 [dostęp: 23 III 2021], dostępny w internecie: <https://www.chinadaily.com.cn/a/201911/22/ wS5dd6c738a310cf3e355791e1.html $>$.

21 Shen Chunyao pełni funkcję zastępcy sekretarza generalnego Stałego Komitetu Ogólnochińskiego Zgromadzenia Przedstawicieli Ludowych (parlament chiński) i członka Komitetu Centralnego KPCh. 
porozumienia. Chodziło o to, by działać w warunkach zgody i harmonii społecznej na wszystkich poziomach, aż po władze centralne. Oficjalnie przyjęta koncepcja "demokracji konsultatywnej” to obowiązkowy system konferencji mających wypracować szeroki konsensus społeczny przed podejmowaniem kluczowych decyzji w państwie.

W ramach poszukiwania takiego konsensusu Xi w 2017 r. apelował podczas specjalnego sympozjum z udziałem sił niekomunistycznych, $\mathrm{w}$ tym Ogólnochińskiej Federacji Przemysłu i Handlu oraz innych bez przynależności partyjnej, o podjęcie wspólnych wysiłków z Komunistyczną Partią Chin na rzecz „wielkiego odrodzenia narodu chińskiego”. Podkreślał przy tym, że tradycją jest, iż KPCh słucha opinii partii niekomunistycznych, a praktyka taka jest również ważnym symbolem socjalistycznej demokracji konsultatywnej. Jednocześnie wyraził nadzieję, że siły niekomunistyczne będą w stanie wzmocnić swój polityczny konsensus co do utrzymania przywództwa KPch i podążania ścieżką „socjalizmu o chińskiej charakterystyce"22. Xi Jinping, prezentując ją na forach partyjnych i parlamentarnych, dodawał, że obok "demokracji konsultatywnej” niezbędna jest także "demokracja wyborcza”. Traktował te dwie podstawowe składowe jako fundament "demokracji o chińskiej specyfice”. Powoływał się przy tym wyraźnie na chińskie tradycje życia politycznego i konfucjańską zasadę, że „lud jest w państwie najważniejszy”. W opinii Krzysztofa Gawlikowskiego te nowe koncepcje ustrojowe mogą się okazać w Chinach trwałą tendencją, mimo czasowych zahamowań i potknięć, gdyż zdają się być dość skuteczną formą dostosowywania instytucji oraz norm zapożyczanych z Zachodu do warunków i tradycji chińskich. Podobnie postrzega te innowacje wielu innych badaczy, którzy jednak podkreślają, iż podstawowy motyw stanowi utylitaryzm KPCh, a konkretnie sprawa utrzymania się przy sterach władzy. Na przykład związany z Uniwersytetem Oxfordzkim Steve Tsang w analizie z 2009 roku konstatuje, że komunizm rzeczywiście przestał być ideologią państwową w Chinach, co nastąpiło w przedziale czasowym między protestami na placu Tiananmen w 1989 roku a upadkiem komunizmu w Europie Wschodniej i Związku Sowieckim. Jednak typowy leninowski system polityczny został tam zachowany, nawet

22 A. Baijie, Xi reaches out to non-Communist parties for report, „China Daily” [online], 16 X 2017 [dostęp: 23 III 2021], dostępny w internecie: 〈https://www.chinadaily.com. cn/china/2017-10/16/content_33311316.htm>. 
jeśli w znacznie zmodyfikowanej postaci. Od tego czasu partia komunistyczna narzuciła obywatelom Chin swego rodzaju umowę społeczną: partia zapewnia Chińczykom stabilność, porządek, szybki wzrost gospodarczy i ogólną poprawę warunków życia w zamian za respektowanie jej dominacji, tj. ciągłego pozostawania na czele ogólnie pojmowanych rządów i w sferze polityki. „Ogólna poprawa warunków życia” obejmuje nie tylko dobrobyt gospodarczy, ale także szerszy zakres wolności jednostki i lepszą zdolność reagowania władz na potrzeby społeczne ${ }^{23}$.

\section{Rozwaga i cierpliwość - część imperialnego DNA Chin}

Stabilność polityczna i umacniająca się pozycja gospodarcza Chin już w lat 90. inspirowała działające tam think tanki, ekspertów akademickich, kadrę wojskową, a także urzędników wysokiego szczebla do refleksji nad miejscem Państwa Środka w światowym układzie sił. W efekcie pojawiły się postulaty restrukturyzacji polityki zagranicznej, generalnie artykułujące potrzebę rezygnacji z obowiązującego modelu defensywnego i zastąpienia go zasadą proaktywności. Zwłaszcza wśród konserwatywnych naukowców narastało przekonanie, że nie do zaakceptowania jest stan rzeczy, polegający w dużym stopniu na przyjmowaniu norm międzynarodowych, definiowanych przede wszystkim przez mocarstwa zachodnie. Zainteresowanie sprawami polityki zagranicznej syǵnalizowała także chińska opinia publiczna, zwłaszcza w sytuacji napięć regionalnych wielu blogerów i internautów często krytykowało chińską politykę np. w kwestii Morza Południowochińskiego, uznając ją za zbyt „nieśmiałą”. Kryzys w stosunkach z Filipinami na spornej ławicy Scarborough doprowadził w maju i w czerwcu 2012 r. do licznych komentarzy w Internecie, w tym wezwań do twardszego stanowiska Chin. Od wielu lat ludność Państwa Środka i diaspora krytykują "niewystarczającą" ochronę chińskich obywateli i mniejszości za granicą. Jednocześnie rosną w świecie obawy przed silnymi Chinami, zwłaszcza wśród sąsiednich krajów w Azji Południowo-Wschodniej, gdzie potęguje je rosnący na przestrzeni lat budżet obronny $\mathrm{Chin}^{24}$ i słabnąca pozycja USA. Na okres ten

23 S. Tsang, Consultative Leninism. China's new political framework, „Journal of Contemporary China" 2009, issue 18(62), s. 865-880.

24 Według raportu SIPRI wydatki wojskowe Chin w 2019 r. wyniosły 261 mld dolarów, co daje im drugie miejsce w świecie. W opinii niektórych ekspertów, 
przypada sprawa zdefiniowania podstawowych interesów, ujętych w ogłoszonej we wrześniu 2011 r. Białej księdze w sprawie pokojowego rozwoju Chin. Za takowe, a więc wymagające zdecydowanej obrony Chin, uznano: „suwerenność państwa, bezpieczeństwo narodowe, integralność terytorialną i zjednoczenie narodowe, ustrój polityczny Chin ustanowiony konstytucją, ogólną stabilność społeczną oraz podstawowe zabezpieczenia zapewniające zrównoważony rozwój gospodarczy i społeczny"25.

Od pewnego czasu do listy podstawowych spraw zaczęto włączać interesy ChRL na Morzu Południowochińskim, Tajwan, Tybet i Hong Kong. Generalnie zarysowała się w chińskiej polityce zagranicznej w XXI wieku z jednej strony zwiększona asertywność, a z drugiej nasilona aktywność na rzecz ochrony szeroko pojętych interesów ekonomicznych. Strategia ekspansji gospodarczej, w tym inwestycji zagranicznych zakładała wsparcie ze strony chińskiej dyplomacji, ukierunkowane na ochronę inwestycji chińskich na całym świecie. Niezależnie od tego obowiązywał do pewnego stopnia utrwalony $\mathrm{w}$ chińskiej polityce zagranicznej kanon dwutorowości, polegający na konsekwentnych i szybkich reakcjach w sytuacjach, gdy w grę wchodzą "podstawowe interesy”, podczas gdy w innych przypadkach realizowano podejście bardziej pasywne, elastyczne i często niedookreślone. Za przykład tego ostatniego może służyć stosunek wobec kwestii konfliktu $\mathrm{w}$ regionie Bliskiego Wschodu. Istotne zmiany $\mathrm{w}$ podejściu do polityki zagranicznej datują się od centralnej konferencji KPCh poświęconej kwestiom polityki zagranicznej (Communist Party of China Central Conference on Work Relating to Foreign Affairs) w $2014^{26}$, na której ogłoszono nową erę międzynarodowej aktywności. Oznaczało to definitywne odejście od doktryny Deng Xiaopinga, której istotą była ostrożna i w istocie defensywna dyplomacja, rozważnie powstrzymująca się przed artykułowaniem ambicji do światowego przywództwa, zgodnie z maksymą: „Obserwujcie spokojnie,

m.in. F. Bartelsa z Heritage Foundation, rzeczywiste wydatki są znacznie większe, gdyż do budżetu wojskowego nie są wliczane nakłady na projekty cywilno-wojskowe, w tym technologie 5G czy obejmujące sztuczną inteligencję.

25 China's Peaceful Development, Information Office of the State Council, The People's Republic of China, September 2011, dostępny w internecie [dostęp: 23 III 2021]: 〈http://www.chinaembassy.org.pl/pol/zt/HPFZ/t856146.htm>.

26 The central conference on work relating to foreign affairs was held in Beijing, 29 XI 2014 [dostęp: 23 III 2021], dostępny w internecie: <https://www.fmprc.gov.cn/ mfa_eng/zxxx_662805/t1215680.shtml>. 
zabezpieczcie naszą pozycję: spokojnie rozwiązujcie problemy, ukrywajcie nasze możliwości i czekajcie na właściwy moment, trzymajcie się w cieniu i nigdy nie sięgajcie po przywództwo"27.

W pełnym wymiarze zmianę zrealizował Xi Jinping, od 2012 r. pełniący funkcję sekretarza generalnego Komunistycznej Partii Chin (KPCh), biorąc za podstawę zarówno słabnące wpływy i potencjał Stanów Zjednoczonych, jak i przekonanie o kluczowej pozycji Chin jako aktora światowej sceny gospodarczej. Ogólne podstawy ku temu tworzył rozwój sytuacji międzynarodowej, w tym m.in. fakt, że Chiny mogły umocnić w omawianym okresie swoje pozycje geostrategiczne, rozbudowując infrastrukturę militarną na Morzu Południowochińskim, przedstawiając koncepcję stosunków nowego typu między wielkimi mocarstwami ${ }^{28}$, ogłaszając inicjatywę Nowego Jedwabnego Szlaku, przekształconego w opiewający na biliony dolarów projekt handlowy, inwestycyjny, infrastrukturalny, a generalnie będący sztandarową inicjatywą geopolityczną i geoekonomiczną. Z tego okresu pochodzi też projekt utworzenia pierwszej poza systemem Bretton Woods globalnej instytucji finansowej, tj. Azjatyckiego Banku Inwestycji Infrastrukturalnych. Chiny podjęły również inicjatywy dyplomatyczne wykraczające poza ich bezpośrednią sferę strategicznego zainteresowania w Azji Wschodniej, aktywnie uczestnicząc w takich przedsięwzięciach jak umowa nuklearna z Iranem z 2015 r., utworzyły bazy morskie na Sri Lance, Pakistanie i Dżibuti, a ich siły zbrojne wzięły udział w manewrach morskich z Rosją na Morzu Śródziemnym i na Bałtyku. Nowe podejście do aktywności międzynarodowej odzwierciedla także utworzenie w marcu 2018 r. Chińskiej Międzynarodowej Agencji Rozwoju, która realizuje szerszy zakres zadań, niż było to w sytuacji, gdy funkcjonowała jedynie niewielka struktura $\mathrm{w}$ postaci departamentu pomocy rozwojowej w ministerstwie handlu. Podkreślić należy w tym miejscu jeszcze jeden, i to szczególnie istotny, aspekt $\mathrm{w}$ całokształcie zmian, a mianowicie silnie artykułowaną zwierzchnią rolę KPCh także w sferze polityki zagranicznej. Podstawą była ocena, że KPCh w ostatnim okresie była w tej płaszczyźnie marginalizowana i aby temu przeciwdziałać, $\mathrm{w}$ rezultacie ustaleń podczas przeprowa-

27 Z. Brzezinski, Strategic vision..., s. 81.

28 Tego typu koncepcję Xi sformułował już w 2012 roku, kiedy pełnił funkcję wiceprezydenta ChRL, a następnie przedstawił ją w 2013 podczas wizyty w USA, które są jej głównym adresatem, choć jako wielkie mocarstwa postrzegane są także Rosja, UE, Indie i Japonia. 
dzonej w czerwcu 2018 r. Centralnej Konferencji ds. Spraw Zagranicznych jednoznacznie przywrócono kierowniczą rolę Komitetu Centralnego $\mathrm{KPCh}^{29}$. $\mathrm{W}$ istocie wprowadzony został prymat ideologii nad polityką zorientowaną na podtrzymywanie wzrostu i stabilizacji gospodarczej. Koncepcję w całości dokumentuje dzieło Myśl Xi Jinpinga w kwestii dyplomacji [ang. Xi Thought on Diplomacy], zawierające kierunkowe zadania polityki zagranicznej $\mathrm{Chin}^{30}$ przyjęte na konferencji poświęconej polityce zagranicznej, która odbyła się w 2018 r. $^{31}$.

Odzwierciedlają to m.in. następujące uwagi i tezy ${ }^{32}$ jego wystąpienia:

- Dyplomacja to skoncentrowany przejaw woli państwa. Trzeba zachować całą władzę nad polityką zagraniczną w rękach Komitetu Centralnego...

- Partie polityczne, rząd, zgromadzenia ludowe, Chińska Ludowa Polityczna Konferencja Konsultacyjna, wojsko, władze lokalne i społeczeństwo obywatelskie muszą zadbać o koordynację, wnosząc własny wkład, tak aby stworzyć nowe warunki aktywności zewnętrznej pod ogólnym kierownictwem partii, która koordynuje całość aktywności i zapewnia realizację polityki zagranicznej oraz strategii Komitetu Centralnego KPCh.

- Kadry są decydującym czynnikiem w ustaleniu kursu politycznego, dlatego nieodzowne jest stworzenia silnego kontyngentu kadr do spraw zagranicznych, lojalnych wobec KPch, kraju i ludzi, solidnych politycznie, kompetentnych zawodowo i silnie zdyscyplinowanych w swoim postępowaniu.

- Kadry aktywne w sprawach zagranicznych muszą poprawić edukację, ideały i przekonania, aby podnieść kompetencje i ogólną jakość, w tym poprzez poprawę warunków życia personelu pracującego za granicą, by uwolnić go od obaw i zmartwień.

29 Ji Wang, Xi Jinping's 'major country diplomacy.' A paradigm shift?, „Journal of Contemporary China" 2019, vol. 28, issue 115, dostępny w internecie [dostęp: 23 III 2021]: 〈https://doi.org/10.1080/10670564.2018.1497907〉.

$30 \mathrm{Ch}$. Gao, Amid tensions with US, China holds an unusually high-level meeting on diplomacy, "The Diplomat" [online], 25 VI 2018 [dostęp: 23 III 2021], dostępny w internecie: <https://thediplomat.com/2018/o6/amid-tensions-with-us-china-holds-anunusually-high-level-meeting-on-diplomacy/ $>$.

31 T. Eder, China's new foreign policy setup. How has Xi Jinping remade China's foreign policy apparatus?, "The Diplomat” [online], 01 VIII 2018 [dostęp: 23 III 2021], Dostępny w internecie: 〈https://thediplomat.com/2018/o8/chinas-new-foreign-policy-setup/〉.

32 Xi urges breaking new ground in major country diplomacy with Chinese characteristics, Xinhuanet, 24 VI 2018 [dostęp: 23 III 2021], dostępny w internecie: <http://www. xinhuanet.com/english/2018-06/24/c_137276269.htm>. 
- Nieodzowne jest przeprowadzenie reformy instytucji i mechanizmów dotyczących spraw zagranicznych zgodnie z decyzją centralnego kierownictwa partii oraz wzmocnienie oddziaływania partyjnego $\mathrm{w}$ instytucjach za granicą, tak aby stworzyć mechanizm zarządzania odpowiedni do wymagań nowej ery.

Konferencja przyniosła radykalną zmianę polityki zaǵranicznej poprzez rozszerzenie jej o wymiar globalny z koncentracją na nowych zagrożeniach bezpieczeństwa, stosunkach międzynarodowych nowego typu, wspólnocie losów ludzkości oraz obronie wolnego handlu i globalizacji. Jednocześnie Chiny deklarowały wolę umacniania swojej pozycji na arenie światowej poprzez gęstą sieć partnerstw z różnymi krajami, aktywnie dążąc do multilateralizmu i globalizacji, a jednocześnie demonstrując sprzeciw wobec unilateralnej polityki Stanów Zjednoczonych. Xi przedstawił wizję chińskiej roli w przewodzeniu zmianom ukierunkowanym na bardziej zrównoważone stosunki międzynarodowe, oparte na wzajemnym szacunku, wzajemnych konsultacjach i współpracy korzystnej dla wszystkich. Podkreślano, iż do odgrywania przewodniej roli predestynuje Chiny status państwa starożytnej cywilizacji, a jednocześnie wiodącej siły w budowie socjalizmu z chińską charakterystyką.

Analitycy zwrócili uwagę, iż ten przedstawiony „nowy model stosunków międzynarodowych" opiera się na dość znanych hasłach unikania konfliktów i konfrontacji, wzajemnym szacunku, współpracy korzystnej dla wszystkich, uczciwości i sprawiedliwości, co powoduje, iż przesłanie nie do końca jest czytelne. Niemniej należy rozumieć, iż w rzeczywistości chodzi o stosunki międzynarodowe, które będą korzystne dla Chin, zwłaszcza jeśli chodzi o podstawowy cel, jakim jest uzyskanie statusu supermocarstwa. Wzajemny szacunek zakłada suwerenny wybór modelu rozwoju i ustroju społecznego, ale dotyczy przede wszystkim „interesów podstawowych", czyli spraw, które Chiny uznają za niepodlegające negocjacjom czy kompromisom. Jak wspomniano, Chiny zademonstrowały swoje globalne ambicje m.in., gdy powołały do życia w 2015 r. Azjatycki Bank Inwestycji Infrastrukturalnych oraz poprzez swój rozwijany od $2013 \mathrm{r}$. sztandarowy projekt, tj. Inicjatywę Pasa i Szlaku, niepokojący głównie Stany Zjednoczone, ale także UE, postrzegające w nim element składowy nowego światowego porządku Pax Sinica i dążenie do zastąpienia nim słabnącego Pax Americana. W optyce wielu ekspertów podstawowy 
błąd amerykańskiej strategii angażowania się (engagement) w Chinach stanowi założenie, że doprowadzi to do fundamentalnych zmian w systemie politycznym, gospodarce $\mathrm{i}$ ich polityce zagranicznej. $\mathrm{W}$ opinii byłego wysokiego urzędnika Departamentu Stanu, Kurta M.Campbella, administracja Donalda Trumpa popełniła podobny błąd, zakładając, że zmiany $\mathrm{w}$ polityce Chin osiągnięte być mogą na drodze konfrontacji ${ }^{33}$. Jego teza i rada są następujące: „Punktem startowym podejścia Stanów Zjednoczonych do chińskiego rywala, winna być nade wszystko świadomość braku strategicznych możliwości podejmowania decyzji, determinujących kierunki długookresowego rozwoju Państwa Środka. Stąd w obecnych uwarunkowaniach koegzystencja polityczna, gospodarcza, militarna, a także w zakresie globalnego przywództwa jawi się jako optymalna strategia, tak z punktu widzenia szeroko pojętych interesów, jak i wartości Zachodnich" ${ }^{\prime 3}$. Ponadto z dzisiejszej perspektywy wyraźnie widać, że wdrożona przez administrację Trumpa zasadnicza zmiana paradyǵmatu polityki handlowej nie spełniła pokładanych nadziei, m.in. nie zmieniła wysokiego ujemnego bilansu handlowego USA. W tej sytuacji Stany Zjednoczone stoją przed koniecznością wypracowania nowej strategii w szczególności w zakresie konkurencji gospodarczej z Chinami.

\section{Bibliografia}

Baijie A., Xi reaches out to non-Communist parties for report, „China Daily” [online], 16 X 2017 [dostęp: 23 III 2021], dostępny w internecie: <https://www.chinadaily.com.cn/china/2017-10/16/content_33311316.htm>.

Banister J., China: Population dynamics and economic implications, [w:] Crisis and reform in China, ed. E. Bliney, Nova Science Publishers, New York 1997.

Brzezinski Z., Strategic vision: America and the crisis of global power, Basic Books, New York 2012.

Campbell K.M., Competition without catastroph, „Foreign Affairs”, September/ October 2019.

China's peaceful development, Information Office of the State Council, The People's Republic of China, September 2011 [dostęp: 23 III 2021], dostępny w internecie: 〈http://www.chinaembassy.org.pl/pol/zt/HPFZ/t856146.htm〉.

33 Zob.: K. M. Campbell, Competition without catastroph, „Foreign Affairs”, September/ October 2019.

34 K. M. Campbell, Competition without catastroph. 
Cieślik E., Rolnictwo w Chinach, rozwój wyzwania i problemy, „Zeszyty Naukowe Szkoły Głównej Gospodarstwa Wiejskiego w Warszawie. Problemy rolnictwa światowego", Rok 2013, t. 13 (XXVIII), z. 2.

Deng Xiaoping, Chińska droga do socjalizmu. Wybór prac z lat 1956 - 1987, przeł. Z. Góralczyk et al., Książka i Wiedza, Warszawa 1988.

Eder T., China's new foreign policy setup. How has Xi Jinping remade China's foreign policy apparatus?, "The Diplomat” [online], O1 VIII 2018 [dostęp: 23 III 2021], dostępny w internecie: < https://thediplomat.com/2018/o8/chinasnew-foreign-policy-setup/>.

Friedberg A. L., A contest for supremacy; China, America and the struggle for mastery in Asia, W. W. Norton\&Company, New York 2011.

Fallaci O., Deng: Cleaning up Mao's mistakes, dostępny w internecie [dostęp: 23 III 2021]: <http://digitalcollections.library.cmu.edu/awweb/ awarchive?type $=$ fileditem $=472059>$.

Fukuyama F., Political order and political decay. From the Industrial Revolution to the globalization of democracy, Profile Books, New York 2014.

Gao Ch., Amid tensions with US, China holds an unusually high-level meeting on diplomacy, "The Diplomat" [online], 25 VI 2018 [dostęp: 23III 2021], dostępny w internecie: <https://thediplomat.com/2018/o6/amid-tensions-with-us-china-holdsan-unusually-high-level-meeting-on-diplomacy/>.

Gawlikowski K., Charakter i dynamika „reform Deng Xiaopinga, SWPS, 4 VI 2014 [dostęp: 23 III 2021], dostępny w internecie: 〈https://www.swps.pl/nauka-i-badania/ materialy-ccaw/2445-charakter-i-dynamika-reform-deng-xiaopinga $>$.

Góralczyk B., Wielki Renesans. Chińska transformacja i jej konsekwencje, Dialog, Warszawa 2018.

Kane P., Population and family politics, [w:] China in the 1990's, eds R. Benewick, P. Wingrove, Macmillan, London 1995.

Kissinger H., On China, The Penguin Press, NY 2011.

J. Rowiński, Upadek Nikity S. Chruszczowa. Czy rzeczywiście była to niewykorzystana szansa zakończenia „zimnej wojny” między Pekinem a Moskwą? Spojrzenie z Zhongnanhai, [w:] Region Azji i Pacyfiku w latach 1985-2015, red. A. Jarczewska, J. Zajączkowski, Scholar, Warszawa 2016.

Programowe dokumenty chinskie z okresu reform, Wybór, opracowanie i przekład K. Gawlikowski, dostępny w internecie [dostęp 23 III 2021]: <https://www.swps. $\mathrm{pl} /$ images/stories/dokumenty/ccaw/gawlikowski/41\%2OPublikacje $\% 20-\% 20$ dokum\%20-Deng-KG-przeklady.pdf $>$.

Rowiński J., Chiny. Nowa globalna potęga, [w:] Dokąd zmierza świat, red. A. D. Rotfeld, PISM, Warszawa 2008.

Tsang S., Consultative Leninism: China's new political framework, „Journal of Contemporary China" 2009, issue 18(62). 
Xi urges breaking new ground in major country diplomacy with Chinese characteristics Xinhuanet, 24 VI 2018 [dostęp: 23 III 2021], dostępny w internecie: <http:// www.xinhuanet.com/english/2018-06/24/c_137276269.htm>.

Wang Ji, Xi Jinping's 'major country diplomacy.' A paradigm shift?, „Journal of Contemporary China" 2019, vol. 28, issue 115, dostępny w internecie [dostęp: 23 III 2021]: 〈https://doi.org/10.1080/10670564.2018.1497907〉.

Westad O. A., Restless empire. China and the world since 1750, Basic Books, London 2012.

Wowra P., Chińska inżynieria społeczna i jej skutki, plportal.pl, 24 II 2019 [dostęp: 23 III 2021], dostępny w internecie: <https://fakty.plportal.pl/artykuly/swiatfelietony/chinska-inzynieria-spoleczna-i-jej-skutki $>$.

Zoellick R., America in the world. A History of U.S. diplomacy and foreign policy, Twelve, New York 2020. 